\title{
Combinatory effects of the bioflavonoid apigenin with chemotherapeutic drugs on prostate, colon, and lung cancer cell lines
}

Lesly Anne J. Lopez

West Virginia University

Follow this and additional works at: https://researchrepository.wvu.edu/etd

\section{Recommended Citation}

Lopez, Lesly Anne J., "Combinatory effects of the bioflavonoid apigenin with chemotherapeutic drugs on prostate, colon, and lung cancer cell lines" (2005). Graduate Theses, Dissertations, and Problem Reports. 2218.

https://researchrepository.wvu.edu/etd/2218

This Thesis is protected by copyright and/or related rights. It has been brought to you by the The Research Repository @ WVU with permission from the rights-holder(s). You are free to use this Thesis in any way that is permitted by the copyright and related rights legislation that applies to your use. For other uses you must obtain permission from the rights-holder(s) directly, unless additional rights are indicated by a Creative Commons license in the record and/ or on the work itself. This Thesis has been accepted for inclusion in WVU Graduate Theses, Dissertations, and Problem Reports collection by an authorized administrator of The Research Repository @ WVU. For more information, please contact researchrepository@mail.wvu.edu. 
Combinatory effects of the bioflavonoid apigenin with chemotherapeutic drugs on prostate, colon, and lung cancer cell lines

\section{Lesly Anne J. Lopez}

Thesis submitted to the Davis College of Agriculture, Forestry and Consumer Sciences at West Virginia University in partial fulfillment of the requirements for fulfillment of the degree of

Master of Science in Genetics

Bing-Hua Jiang, Ph.D., Chair

Jia Luo, Ph.D.

Sharon Wenger, Ph.D.

Department of Genetics and Developmental Biology

Division of Plant and Soil Sciences

\section{Morgantown, West Virginia}

2005

Keywords: apigenin, antioxidant, bioflavonoid, prostate cancer, colon cancer, lung cancer Copyright Lesly Anne J. Lopez 2005 


\title{
ABSTRACT \\ Combinatory effects of the bioflavonoid apigenin with chemotherapeutic drugs on prostate, colon, and lung cancer cell lines
}

\author{
Lesly Anne J. Lopez
}

Lung, prostate, and colon cancer are among the most commonly diagnosed cancers in Americans. Current chemotherapeutic regimens generally have toxic side effects leading to the death of normal cells. Polyphenols are naturally occurring compounds that can be found in fruits, vegetables and herbs. Apigenin is a polyphenolic compound that has been shown to have antioxidant and anti-inflammatory effects. In this study, apigenin was shown to inhibit the proliferation of several cancer cell lines. The combination of 15 $\mathrm{uM}$ apigenin and the chemotherapeutic drugs including doxorubicin, etoposide, mitomycin $\mathrm{C}$, and 5-fluorouracil significantly decreased $(\mathrm{P}<0.05)$ the IC50 to inhibit the proliferation of prostate cancer cell lines PC-3 and DU-145 more than the chemotherapeutic drugs alone. Similarly, the addition of apigenin greatly enhanced the sensitivity of colon cancer cell lines HCT-116 and colo-205 and lung cancer lines A549 and $\mathrm{H} 460$ to doxorubicin, mitomycin C, 5-fluorouracil, and cisplatin. We analyzed sensitivity via cell death and cell proliferation assays. 


\section{Dedication}

Every day God grants me the gift of life is a day that I give thanks to him through my work and my deeds. This work is dedicated to Him.

To my parents, Dr. Amante and Mrs. Josephine Lopez - were it not for you, I would not have taken this path. Your love is stronger than any that I have known, and you are always with me in spirit. Thank you.

To my sister Kristina - I started my work at the bench when I was your age. It humbles me to think that it could have made such an influence on your life.

To my brother Eric - for your technical assistance, masterful implementation of calculus, and pictures of cute cats, thank you.

To my fiancé, Dr. Heath Skinner - you are my protector, teacher, scientific peer, and best friend. I would not be doing this without you. 


\section{Acknowledgements}

I'd like to thank my advisor, Dr. Bing-Hua Jiang, and my graduate committee members, Dr. Jia Luo and Dr. Sharon Wenger, for their input and direction during the course of my graduate career.

Thank you to Dr. Quentin Li and Dr. Weixin Wang for the A549, H460, colo-205, and HCT-116 cell lines.

Thank you to Dr. Amanda Ammer and Dr. Valerie Walker for their advice and direction. 


\title{
Table of Contents
}

Page
iii
iv
v
ii
vi
vii
viii
1
3
7
9
14
A
D
U

\author{
Content \\ Dedication \\ Acknowledgements \\ Table of Contents \\ Abstract \\ Tables \\ List of Figures \\ Symbols \\ Introduction \\ Literature Review \\ Text of Investigation \\ Summary \\ Recommendations \\ Bibliography \\ Figure Legend \\ Curriculum Vitae
}




\section{List of Tables}

Table 2.1 Subclasses of flavonoids

Table 3.1 Characterization of cell lines

Table 4.1 IC50 values of cell lines 


\section{List of Figures}

Figure 2.1 General structure of flavonoids

Figure 2.2 The structure of apigenin

Figure 4.1 Response of prostate cancer cell lines PC-3 and DU-145 to apigenin

Figure 4.2 Response of colon cancer cell lines colo-205 and HCT-116 to apigenin

Figure 4.3 Response of lung cancer cell lines A549 and H40 to apigenin

Figure 4.4 Apigenin induced sensitivity of prostate, colon, and lung cancer cell lines to doxorubicin

Figure 4.5 Apigenin induced sensitivity of the PC-3 and DU-145 prostate cancer cell lines to etoposide

Figure 4.6 Apigenin induced sensitivity of the prostate, colon, and lung cancer cell lines to mitomycin $\mathrm{C}$

Figure 4.7 Apigenin induced sensitivity of the PC-3 and DU-145 prostate and colo205 and HCT-116 colon cancer cell lines to 5-fluorouracil

Figure 4.8 Apigenin induced sensitivity of the colo-205 and HCT-116 colon cancer and A549 and H460 lung cancer cell lines to cisplatin

Figure 4.9 IC50's of prostate, colon, and lung cancer cell lines

Figure 4.10 Comparison of IC50 response to chemotherapeutics with and without apigenin by drug type

Figure 4.11 Comparison of IC50 response to chemotherapeutics with and without apigenin by cell line

Figure 4.12 Apigenin induced sensitivity of the PC-3 and DU-145 prostate cancer cell lines to etoposide 


\section{List of Symbols}

Figures $4.1-4.3$

$\pm \quad$ Cell type response to drug treatment significantly different $(\mathrm{P}<0.05)$ from control

Figures $4.4-4.12$

$\pm \quad$ Cell type I response to drug treatment significantly different $(\mathrm{P}<0.05)$ from control

* $\quad$ Cell type I response to apigenin combination treatment significantly different $(\mathrm{P}<0.05)$ from drug treatment alone

$\mathrm{x} \quad$ Cell type II response to drug treatment significantly different $(\mathrm{P}<0.05)$ from control

\# Cell type II response to apigenin combination treatment significantly different $(\mathrm{P}<0.05)$ from drug treatment alone 


\section{Chapter 1: Introduction}

Although two-thirds of human cancers are preventable by lifestyle changes such as dietary modifications (Katiyar et al 2001), the American Cancer Society reports that in 2005, 6.9 million patients will die of cancer and 10.9 million more will be diagnosed world wide. In the US alone, 570,000 patients will die of cancer and nearly 1.4 million new cases will be diagnosed. The leading cause of cancer death in America is lung cancer followed by prostate cancer, with an expected 170,000 and 230,000 new cases to be diagnosed. Colon cancer, the third most diagnosed cause of cancer in the US, will see about 105,000 new cases in 2005 .

Cancer, or the unregulated growth of cells in the body, can manifest itself in many forms, but they all start out with damage to the DNA. Treatment varies widely with the cancer's point of origin and can vary within each type depending on the individual. Most often, surgery is performed to physically remove the mass of cells. It is most successful in cancers that have not yet spread to any other part of the body. The complications involved with the surgical removal of cancer are the same with any surgical procedure and can include bleeding, damage to internal organs and vasculature, an undesirable reaction to anesthesia, and blood clots. Ionizing radiation is another common method employed with cancer treatment. The power of radiation lies in its ability to physically target rapidly dividing cells. Since growth patterns of cancer cells are abnormal and unregulated, this makes the treatment particularly effective. Radiation can be employed with either photons (x-rays or gamma rays) or particle radiation (alpha or beta particles, protons, neutrons, electrons), but the complications are many. The treatment can only 
discriminate between radiosensitive and non-radiosensitive cells but not cancerous and noncancerous cells, and commonly kills a number of normal cells in the body. The patient undergoing radiation often experiences fatigue and loss of taste, and the patient's skin can undergo peeling and a pigment darkening.

Chemotherapeutic treatments of cancer involve the administration of any number of anticancer drugs via oral, intravenous, or vaccine-like administration. The advantages to chemotherapy over surgery and ionizing radiation are that does not rely on a trained eye to be able to physically discern the cancer before being able to target it, and that it is released into the bloodstream where it can then "seek out" the cancer throughout the body. Like ionizing radiation, its power lies in its ability to target rapidly dividing cells. However, because it works globally throughout the body due to its availability in the blood stream, it also affects the body's high-turnover cells like those in the stomach, mouth, hair and nails. Common drugs include doxorubicin and etoposide for the treatment of prostate cancer, 5-fluorouracil and platinum-based drugs for the treatment of colon cancer, and paclitaxel and vinorelbine for treatment for lung cancer. Combinations of chemotherapeutic drugs are common, such as the addition of leucovorin to 5fluorouracil, and can lead to less severe side effects.

Immunotherapeutic treatments of cancer involve stimulating the body's own natural defenses against invasion. The power of immunotherapy hinges on the often very different characteristics of cancer cells and the body's ability to recognize these cells as abnormal. Treatment can take the form of cancer vaccination, administration of a 
monoclonal antibody therapy, or a nonspecific immunotherapy regimen that can boost the body's immune system overall. Because immunotherapy is a relatively new technique, variety of treatment regimens are slim and little is known yet known about the long-term effects.

\section{Chapter 2: Review of Literature}

Often, a patient's treatment regimen includes a combination of techniques. Surgery with followed by chemotherapy is a common regimen. Chemotherapeutic drugs affect throughout the bloodstream, the drug's mechanism must be eloquently designed in order to affect only cancerous cells. This often means directing the drug towards the unique characteristics of cancer cell and the way it can progress through the cell cycle. One difference between cancer cells and normal cells is its p53-dependent status. When a normal cell has damaged DNA, this signals the tumor-suppressor protein p53 and the cell cycle kinase inhibitor p21 to activate (Manic et al 2003). This leads to an arrest of growth in the G1 or G2 growth phase of the cell cycle, making it unable to for the damaged cell to continue into mitosis (Cui et al 2002). If a particular form of cancer lacks these p53 or p21 tumor suppressors, the cell cycle continues on having lacked any signal to turn itself off. This leads to a proliferation of DNA-damaged cells.

A potential new cancer treatment also includes targeting the nuclear factor kappa B (NF-kappaB) pathway. NF-kappaB has been implicated in regulation of cell growth, apoptosis, inflammation and the stress response (Lin et al 2003, Li et al 2002, Karin et al 
2002). Its involvement on multiple cancers makes it a good target for chemotherapy. The PI3K / AKT pathway activates a number of growth factors and cytokines unique to the life span of a cancer cell. Its activation promotes cell survival by inhibiting apoptosis by inactivating anti-apoptotic factors (Brenet et al 1999, Cardone et al 1998). The overexpression of members of this pathway also make it a good target for chemotherapeutic drugs. Another target of chemotherapy is the MAPK pathway, a threetiered kinase set consisting of MAP3K, MAP2K, and a MAPK, which can be ERK, JNK, or p38. When activated, these MAPKs can lead to NF-kappaB, increased cell growth and survival (Sebolt-Leopold 2000, Seger and Krebs 1995). These characteristics found in cancer cells help make the MAPK pathway a useful target for chemotherapy.

Polyphenols are naturally-occurring antioxidants found in plants that have been shown to have effects on biological activity. Classified as flavonoids, phenolic acids, stilbenes, lignans, they are found in red wine, tea, fruits, and vegetables (Kuroda et al 1999). Recently, their antioxidant properties have been shown play a role in cell survival (Chen et al 2000), cell cycle arrest (Yoshida et al 1990, Ranelletti et al 1992, Lepley et al 1996), and cell cycle enzyme arrest (Formica 1995, Cos et al 1998, Dugas et al 2000, Pietta et al 2000). Naturally-occuring compounds like the flavonoids (Fig. 2.1), the most abundant group of plant polyphenols, have been recently showed to inhibit tumor growth (Formica and Regelson 1995, Kobyashi et al 2002). The chemopreventative effects of these flavanoids have been studied in stomach, esophagus, duodenum, pancreas, liver, breast, colon, lung, and skin cancers in addition to the elucidation of their role in 
atherosclerosis, cholesterol, and blood pressure (Nachshon-Kedmi et al 2002, Kim et al 1998, Kris-Etherton PM \& Keen CL 2002).

Flavonoids have four subclasses divisible by structure, and each subclass has a number of developing chemotherapeutic drugs (Table 2.1). The flavanols, flavones, isoflavones, flavonols, and anthocyanidins have yielded enormous success as pre-clinical trial chemotherapeutics (Gao et al 1999, Fotsis et al 1997). The structure of a flavonoid itself is comprised of two benzene rings connected by an $\mathrm{AC}$ ring, with the $\mathrm{C}$ ring and C2-C3 double bonds correlating with anti-proliferative activity and apoptosis (Deguchi et al 2002, Choi et al 2005, Etherton et al 2002, Gao et al 1999, Gupta et al 2003).

One flavone of interest is apigenin, also known as 4', 5, 7 trihydroxyflavone (Fig. 2.2). Apigenin has been classified as a nonmutagenic antioxidant and free radical scavenger with low toxicity (Birt et al 1986, Duthie et al 2001). It has been to shown to have anti-inflammatory properties in prostate cancer (Gupta et al 2001, Casagrande and Darbon 2001), be able to arrest the cell cycle arrest in colon and prostate cancer (Wang et al 2000, Gupta et al 2002) and to slow down growth and metastatic potential in melanoma (Caltagrione et al 2000). In neuroblastoma, apigenin has the potential to inhibit tumor growth, cell viability and induce caspase-dependent apoptosis in a p53 dependent manner in neuroblastoma and cervical cancer (Torkin et al 2005, Zheng et al 2005). Apigenin has also been shown to induce a dose-dependent phosphorylation of ERK and p38 kinase but not JNK (Van Dross et al 2003), and to cause endothelial cell 
death with increasing reactive oxygen species levels via JNK- and p38 MAPK-responsive activation (Choi et al 2005).

Previously, our laboratory has shown apigenin to inhibit VEGF / HIF-1 expression through the PI3K / AKT and p53 pathways (Fang et al 2004). Previous work from our laboratory showed that apigenin affects decreases cell proliferation in PC-3 and DU145 prostate cancer cells in a dose-dependant manner. Combining apigenin with cisplatin was also shown to significantly decrease cell proliferation and increase apoptosis in a cisplatin-resistant variant of the A2780 ovarian cancer cell line, CP70, over cisplatin alone.

Currently, surgery or radiation combined with chemotherapy is the most common treatment of cancer. However, standards of health can decrease due to the toxic effects of any of these treatments. Radiation can decrease surfactant production so lungs don't inflate completely or cause stiffening or scarring, a condition called fibrosis. In the prostate, sexual dysfunction can occur. A recent development in chemotherapeutics the administration of drugs in combination to maximize cancer-killing properties with the least amount of non-specific toxicity drugs are now being administered (Calviello et al 2005). Here, we propose that the non-mutagenic dietary flavanoid apigenin be combined with current chemotherapeutic drugs to enhance their effects without additional toxic effects. 


\section{Chapter 3: Text of Investigation}

In order to determine whether apigenin exerts a sensitizing effect on cancer drugs undergoing chemotherapy, we chose a variety of cell lines: the p53 mutant prostate cancer cell lines PC-3 and DU-145, the p53 mutant colo-205 and p53 wild-type HCT-116 colon cancer cell lines, and the p53 wild-type A549 and H460 lung cancer cell lines (Table 3.1).

\section{Materials and Methods}

\section{$\underline{\text { Cell Culture }}$}

PC-3 cells (ATCC CRL-1435) were grown in RPMI supplemented with $10 \%$ fetal calf serum, $2 \mathrm{mM}$ L-glutamine and $1 \%$ penicillin/streptomycin. Subcultivation was completed every 2-3 days with a $0.025 \%$ trypsin solution at a 1:10 ratio.

DU-145 cells (ATCC HTB-81) were grown in DMEM supplemented with 10\% fetal bovine serum, $2 \mathrm{mM}$ L-glutamate and $1 \%$ penicillin/streptomycin. Subcultivation was done once every $6-7$ days with at $0.025 \%$ trypsin solution at a $1: 5$ ratio.

Colo-205 cells (ATCC CCL-222) were grown in RPMI 1640 supplemented with 10\% fetal bovine serum, $2 \mathrm{mM}$ L-glutamine, $1.5 \mathrm{~g} / \mathrm{L}$ sodium bicarbonate, $4.5 \mathrm{~g} / \mathrm{L}$ glucose, 10 $\mathrm{mM}$ HEPES, $1.0 \mathrm{mM}$ sodium pyruvate, and $1 \%$ penicillin/streptomycin. Subcultivation was done every 5-6 days with a $0.025 \%$ trypsin solution at a 1:5 ratio.

HCT-116 cells (ATCC CCL-247) were grown in McCoy's 5a medium supplemented with $10 \%$ fetal bovine serum, $1.5 \mathrm{mM} \mathrm{L-glutamine,} \mathrm{and} 1 \%$ penicillin/streptomycin. Subcultivation was done every $3-4$ days with a $0.025 \%$ trypsin solution at a $1: 10$ ratio. 
A549 cells (ATCC CCL-185) were grown in RPMI supplemented with 10\% fetal calf serum, 2 mM L-glutamate and $1 \%$ penicillin/streptomycin. Subcultivation was done every 2-3 days with a $0.025 \%$ trypsin solution at a 1:6 ratio.

H460 cells (ATCC HTB-177) were grown in RPMI supplemented with 10\% fetal calf serum, 2 mM L-glutamate and $1 \%$ penicillin/streptomycin. Subcultivation was done every $4-5$ days with a $0.025 \%$ trypsin solution at a 1:8 ratio. All cells were incubated at $37 \mathrm{C}$ in a $5 \% \mathrm{CO}_{2}$ controlled environment and had their media refreshed every three days.

\section{$\underline{\text { Drug Treatments }}$}

Chemotherapeutic drugs used include: doxorubicin hydrochloride, an inhibitor of reverse transcriptase and RNA polymerase; cisplatin, a repair mechanism inhibitor; etoposide, a DNA cleavage enhancer; mitomycin C, a DNA synthesis and nuclear division inhibitor, and 5-fluorouracil, a DNA synthesis inhibitor. The chemotherapy drugs doxorubicin, mitomycin $\mathrm{C}$, etoposide, 5-fluorouracil, and cisplatin as well as the flavanol apigenin were all obtained from Sigma Aldrich.

\section{Cell proliferation assays}

Cell proliferation assays were measured via MTT absorption. Cells were plated in 96-well plates (Corning Life Sciences) at $1 \times 10^{4}$ cells per well in $100 \mathrm{uL}$ of feeding media and were allowed to adhere overnight. The next day, the media was removed and replaced with fresh medium or treatment doses. Cells were incubated at $37 \mathrm{C}$ for 24 hours before the addition of $10 \mathrm{uL}$ of $5 \mathrm{mg} / \mathrm{mL}$ thiozolyl blue tetrazolium bromide reagent (Sigma Aldrich). After another $2 \mathrm{hr}$ incubation, the reaction was stopped by adding 100 
$\mathrm{uL}$ of solubilization solution. Measurements were taken using a spectrophotometer at 470 nm after 4 hours.

\section{Cell Death:}

Cell death was measured via trypan blue exclusion. Cells were plated at $1 \times 10^{6}$ in 6 well plates and allowed to adhere overnight. The next day, the plating medium was removed and cells were washed with 1x PBS before serum starving for 8 hours. The media was then refreshed and drug treatments administered for 6 hours. The cells were then washed with $1 \times$ PBS, detached with $0.025 \%$ trypsin, spun at 2000 RPM at $4 \mathrm{C}$ for 5 minutes, aspirated, and resuspended in $1 \mathrm{~mL} 1 \mathrm{x}$ PBS. An aliquot of this suspension was then stained with an equal volume of trypan blue (Gibco-BRL) and counts of live and dead cells were done using a hematocytometer.

\section{Statistical Analysis}

Significant differences were calculated using ANOVA with $p<0.05$. IC50's were calculated using a regression calculation.

\section{Chapter 4: Summary and Conclusions}

\section{Summary}

\section{Effects of Apigenin on Different $\underline{\text { Cell Types }}$}

To study the effect of apigenin on cell proliferation, the cells were treated with apigenin at various doses. In PC-3 and DU-145 cell lines, $10 \mathrm{uM}$ or higher of apigenin alone significantly decreased cell proliferation $(\mathrm{P}<0.05$, Fig. 4.1). The apigenin has 
similar inhibitory effects on colon cancer cell lines. The apigenin treatment at $15 \mathrm{uM}$ significantly decreased cell proliferation in colo-205 and HCT-116 (Fig. 4.2). HCT-116 cells were much more sensitive to 15 and $20 \mathrm{uM}$ of apigenin. The effects of apigenin are similarly observed in other human cancer cells including A549 and H460 cells (Fig. 4.3).

The Combination effects of Apigenin with Chemotherapy Drugs

Doxorubicin: To study the effect of apigenin combined with doxorubicin on cell proliferation, PC-3 cells were treated by doxorubicin alone or in combination with $15 \mathrm{uM}$ apigenin. Our data showed that apigenin treatment alone greatly decreased cell proliferation (Fig. 4.4a). We used a similar method to treat DU-145 cells and found that apigenin treatment alone was sufficient to inhibit cell proliferation and the addition of doxorubicin did not further enhance the effect (Fig. 4.4b). For colon cancer cell lines, the combination treatment of apigenin and doxorubicin has synergistic or additive effects to inhibit cell proliferation, especially Colo-205 cells (Fig. 4.4c). However, there were no significant differences with or without the drug treatment in A549 and H460 cells when combined with apigenin (Fig. 4.4d).

Etoposide: With etoposide treatment in prostate cancer cells, PC-3 (Fig. 4.5a) cells seemed more sensitive to drug treatment with and without apigenin that did the DU145 (Fig. 4.5b).

Mitomycin C: To study the effect of apigenin combined with the chemotherapeutic drug mitomycin $\mathrm{C}$, we observed that low doses of mitomycin $\mathrm{C}$ were 
sufficient to inhibit cell proliferation in either PC-3 or DU-145 prostate cancer cell lines and the addition of apigenin increased sensitivity of the cells to mitomycin C (Fig. 4.6a). In the colon cancer cell lines colo-205 and H460, the effects of the combination therapy between mitomycin $\mathrm{C}$ and apigenin has significantly higher inhibitory effect that mitomycin C alone(Fig. 4.6b).

Similarly in A549 and H460 lung cancer cell lines, the combination treatment between mitomycin $\mathrm{C}$ and apigenin has significantly higher inhibitory effect than mitomycin $\mathrm{C}$ alone (Fig. 4.6c). Although both showed a significant decrease in cell proliferation when treating with mitomycin $\mathrm{C}$ alone, the inhibitory effect on $\mathrm{H} 460$ cell lines is nearly two-fold stronger than that in A549 cells.

5-Fluorouracil: In PC-3 and DU-145 cells, the combination treatment of apigenin and 5-fluoruracil alone significantly decreased cell proliferation compared to the 5-fluorouracel alone (Fig. 4.7a). Similarly, the combination treatment of apigenin and 5fluorouracil significantly decreased colo-205 colon cancer cells at 5 and $10 \mathrm{uM}$ than with 5-fluorouracil alone (Fig. 4.7b). The HCT-116 in comparison were much more sensitive when treated by the combination of apigenin and 5-fluorouracil (Fig. 4.7c)

Cisplatin: The combination treatment of apigenin and cisplatin significantly decreased cell proliferation at 0.5 and $1 \mathrm{uM}$ cisplatin (Fig. 4.8a). In both colo-205 and the HCT-116, the synergistic inhibitory effect was no longer observed when the cells were treated by cisplatin at 5 and $10 \mathrm{uM}$ (Fig. 4.8a). In H460 lung cancer cells, significant 
differences in cell proliferation were observed by the combination treatment than cisplatin alone (Fig. 4.8b). However, the combination of apigenin and cisplatin did not significantly affect cell proliferation in A549 cells (Fig. 4.8b).

\section{Conclusions}

\section{Apigenin, when combined with a range of chemotherapeutic drugs, can increase the sensitivity of prostate, colon, and lung cancer cells to halt cell proliferation.}

Apigenin has been shown previously to be a non-mutagenic, low toxicity compound, but it is important to keep in mind that each type of cancer would react differently to treatment with it, as evidenced by the range in IC50 values as described in Fig. 4.9. Here, apigenin's ability to increase a cell line's sensitivity to a particular chemotherapeutic was measured by its ability to lower IC50 threshold. Based on the ranges in response, apigenin's ability to sensitize depends on cell type. While PC-3 cells show significant differences in combination treatment over doxorubicin, 5-fluorouracil and mitomycin C treatment alone over DU-145 cells at a range of doses (Fig. 4.4a, 4.4b, 4.6a, 4.6b, 4.7a, and 4.7b), neither the PC-3 nor the DU-145 IC50 were significant (Fig. 4.10a and 4.10b). However, etoposide treatment in both PC-3 and DU-145 cells showed significant differences in IC50 values (Fig. 4.12a and 4.12b). Similarly, while colo-205 and HCT-116 showed significant differences in combination treatment over single drug treatment over a range of doses for a number of drugs, significant differences in IC50 values were only seen in doxorubicin and mitomycin $\mathrm{C}$ for both and 5-fluorouracil for HCT-116 (Fig. 4.10c and 4.10d). In lung cancer cells, significant differences in 
combination treatment not seen with single drug treatment in A549 and H460 cells were found cisplatin and mitomycin $\mathrm{C}$ treatment (Fig. 4.10e and 4.10f).

\section{When combined with apigenin, IC50 values of potentially toxic chemotherapeutics on some prostate, lung, and colon cancer cell lines decreased significantly.}

A standard measure of how toxic a particular drug is to an organism is its IC50 value, or the dosage that would be required to kill off have the cells. Here, we measured IC50 values using cell proliferation. As noted by Figures 4.9 - 4.11 and Table 4.1, there is a range in how much a drug would be required to hit the IC50 value from cell line to cell line. However, in most cases, the addition of apigenin alone seemed to significantly decrease amount of chemotherapeutic drug required to kill off half the cells (Fig. 4.9). Apigenin combined with doxorubicin exerted the greatest change over drug alone on IC50 values on PC-3, A549, and H460 cells (Fig. 4.10a), and mitomycin C exerted the greatest change over drug alone on colon and lung cancer lines (Fig. 4.10b). When combined with 5-fluorouracil, apigenin showed the greatest effect on IC50 values on HCT-116 and A549 cells (Fig. 4.10c), and combined with cisplatin, it showed the greatest effect on DU-145 and colo-205 cells (Fig. 4.10d). On IC50 values from etoposide treatment, apigenin exerted significantly different effects in combination on both PC-3 and DU-145 prostate cancer cell lines. 
The possibility of using apigenin in combination is promising. Many naturallyoccurring phenolic compounds are now being to see how their antioxidant effects could prove useful in decreasing the amount of toxins one must administer in order to undergo chemotherapy regimens successfully, such as genestein and (-) epigallocatechin-3-gallate. Apigenin's properties as an anti-inflammatory make it also intriguing in the realm of creating new, safe supplements to treat or manage cardiovascular health. Because of its ability to create the same clinical effect with a reduced amount of chemotherapy and its ability to potentially treat resistant forms of cancer, apigenin's involvement in a number of pathways implicated in variety of cancers makes it an intriguing addition to the recent focus on nutriceuticals.

\section{Chapter 5: Recommendations}

In order to get a more accurate picture of how cancer cells respond to sensitivity to chemotherapeutics when treated with apigenin, further experiments should be carried out in normal non-cancerous prostate, lung, and colon cell lines. A comparison of these cell types to the cancerous variants would give a more complete indication of whether significant differences of cell proliferation could be seen.

Here, cell death was measured by trypan blue exclusion. For distinction between apoptosis and necrosis in measures of cell death, more accurate measures of apoptotic markers such as Annexin V staining or determination of the caspase proteins should be taken. 


\section{Bibliography}

Birt DF, Walker B, Tibbels MG and Breskinck E. Antimutagenesis and anti-promotion by apigenin, robinetin and indole-3-carbinol. Carcinogenesis 7: 959-963. 1986.

Caltagirone S, Rossi C, Poggi A, Ranelletti FO, Natali PG, Brunetti M, Aiello FB, and Piantelli S. Flavonoids apigenin and quercetin inhibit melanoma growth and metastatic potential. Int J Cancer 87: 595-600. 2000.

Calviello G, Di Nicuolo F, Serini S, Piccioni E, Boninsegna A, Maggiano N, Ranelletti FO, and Palozza P. Docosahexaenoic acid enhances the susceptibility of human colorectal cancer cells to 5-fluorouracil. Cancer Chemother Pharacol 55:12-20. 2005.

Casagrande F and Darbon JM. Effects of structurally related flavonoids on cell cycle progression of human melanoma cells: regulation of cyclin-dependent kinases CDK2 and CDK1. Biochem Pharmacol 2001; 61: 1205-15.

Chen C, Yu R, Owuor ED, and Kong AN. Activation of antioxidant-response element (ARE), mitogen-activated protein kinases (MAPKs) and caspases by major green tea polyphenol components during cell survival and death. Arch Pharm Res 23: 605-12. 2000 .

Choi YJ, Jeong YJ, Kwon HM, and Kang YH. (-) Epigallocatechin gallate and quercetin enhance survival signaling in response to oxidant-induced human endothelial apoptosis. $\mathrm{J}$ Nutr 135: 707-13. 2005.

Cui H, Schroering A, and Ding HF. P53 mediate DNA damaging drug-induced apoptosis through a caspase-9-dependent pathway in SH-SY5Y neuroblastoma cells. Mol Cancer Ther 2002; 1: 679-86.

Deguchi H, Fujii T, Nakagawa S, Koga T, Shirouzu K. Analysis of cell growth inhibitory effects of catechin through MAPK in human breast cancer cell line T47D. Int J Oncol 21: 1301-1305. 2002.

Duthie G, and Crozier A. Plant-derived phenolic antioxidants. Curr Opin in Clin Nutr and Metab Care 3, 447-451. 2000.

Fotsis T, Pepper MS, Aktas E, Breit S, Raksu S, Adlecreutz H, Wahala K, Montesano R and Schweigerer L. Flavonoids, dietary-derived inhibitors of cell proliferation and in vitro angiogenesis. Cancer Res. 57: 2916-21. 1997.

Gao Z, Huang K, Yang X \& Xu H. Free radical scavenging and antioxidant activities of flavonoids extracted from the rasix of Scutellaria baicalensis. Georgi Biochim Biophys Acta 1472: 643-650. 1999. 
Gupta S, Afaq F, Mukhtar H. Involvement of nuclear factor-kappa B, Bax and Bcl-2 in induction of cell cycle arrest and apoptosis by apigenin in human prostate carcinoma cells. Oncogene 21: 3727-38. 2002.

Gupta S, Hussain T, Mukhtar H. Molecular pathway for (-) epigallocatechin-3-gallateinduced apoptosis of human prostate carcinoma cells. Arch Biochem Biophys 410: 17785. 2003.

Katiyar SK, Afak F, Perez A, and Mukhtar H. Green tea polyphenol (-)-epigallocatechin3-gallate treatment of human skin inhibits ultraviolet radiation-induced oxidative stress, Carcinogenesis 22 (2001) 287-294.

Kim HP, Mani I, Iversen L, and Ziboh VA. Effects of naturally-occurring flavonoids and bioflavonoids on epidermal cyclooxygenase and lipoxygenase from guinea-pigs. Prostagland, Leuko, and Essen Fatty Acids 58: 17-24. 1998.

Kobyashi T, Nakata T, and Kuzumakia T. Effect of flavonoids on cell cycle progression in prostate cancer cells. Cancer Lett 2002:176:17-23.

Kris-Etherton PM \& Keen CL. Evidence that the antioxidant flavonoids in tea and cocoa are beneficial for cardiovascular health. Curr Opin Lipidol 13: 41-49. 2002.

Manic S, Gatti L, Carenini N, Fumagalli G, Zunino F, and Perego P. Mechanisms controlling sensitivity to platinum complexes: role of p53 and DNA mismatch repair. Curr Cancer Drug Targets 3: 21-29. 2003.

Nachshon-Kedmi M, Yannai S, Haj A, and Fares FA. Indole-3-carbinol and 3,3'diindolymethane induce apoptosis in human prostate cancer cells. Food Chem Toxicol 41: 745-52. 2003.

Sarkar FH, Li Y. Cell signaling pathways altered by natural chemopreventative agents. Mutation Research 555: 53-64. 2004.

Sebolt-Leopold. Development of anticancer drugs targeting the MAPK pathway. Oncogene 19: 6594-99. 2000.

Seger R and Krebs EG. The MAPK signaling cascade. FASEB J 9: 726-33. 1995.

Torkin R, Lavoie JF, Kaplan DR, and Yeger H. Induction of caspase-dependent, p53mediated apoptosis by apigenin in human neuroblastoma. Mol. Cancer Ther 4(1). 2005.

Van Dross R, Xue Y, Knudson A, and Pelling JC. The chemopreventative bioflavonoid apigenin modulates signal transduction pathways in keratinocyte and colon carcinoma cell lines. J Nutr 133: 3800S-3804S. 2003. 
Wang W, Heiderman L, and Chung CS. Cell-cycle arrest at G2/M and growth inhibition by apigenin in human colon carcinoma cell lines. Mol Carciong 2000: 28: 102-10.

Zheng PW, Chiang LC, and Liu CC. Apigenin induced apoptosis through p53-dependent pathway in human cervical carcinoma cells. Life Sciences 76: 1367-79. 2005. 


\section{Appendix: Figure Legend}

Table 2.1. Subclasses of flavonoids involved in cancer signaling pathways.

Flavanoids are naturally-occuring polyphenol compounds with antioxidant properties. Many have been implicated to be involved in cell signaling pathways.

\begin{tabular}{|l|l|}
\hline Flavonols & myricetin, quercetin \\
\hline Flavones & apigenin, luteolin \\
\hline Isoflavones & genistein, luteone \\
\hline Flavonones & hesperiden, pinocembrin \\
\hline Flavanols & \\
\hline Anthocyanidins & epicatechin \\
\hline
\end{tabular}


Table 3.1. Characterization of cell lines.

The PC-3 and DU-145 prostate cancer cell line as well as the Colo- 205 colon cancer cell line have been characterized as having a mutant $\mathrm{p} 53$ tumor suppressor status, and therefore is unable to halt damaged DNA from going through the cell cycle. The HCT116 colon cancer cell line as well as the A549 and H460 lung cancer cell line has been characterized with normally behaving wild-type p53 tumor suppressor.

\begin{tabular}{|l|l|l|}
\hline Cell line & Origin & P53 statuS \\
\hline PC-3 & $\begin{array}{l}\text { Epithelial prostate } \\
\text { adenocarcinoma }\end{array}$ & Mutant \\
\hline DU-145 & $\begin{array}{l}\text { Epithelial prostate } \\
\text { carcinoma }\end{array}$ & Mutant \\
\hline Colo-205 & $\begin{array}{l}\text { Epithelial colorectal } \\
\text { adenocarcinoma }\end{array}$ & Mutant \\
\hline HCT-116 & $\begin{array}{l}\text { Epithelial colorectal } \\
\text { carcinoma }\end{array}$ & Wild-type \\
\hline A549 & $\begin{array}{l}\text { Epithelial lung } \\
\text { carcinoma }\end{array}$ & Wild-type \\
\hline H460 & $\begin{array}{l}\text { Epithelial lung } \\
\text { carcinoma }\end{array}$ & Wild-type \\
\hline
\end{tabular}


Table 4.1. IC50 values of cell lines.

The IC50 values of cell lines varied with cell type and drug type.

\begin{tabular}{|c|c|c|c|}
\hline Drug & Cell Line & 0 uM apgigenin & 15 uM apigenin \\
\hline \multirow[t]{6}{*}{ Doxorubicin } & PC.3 & 7.669 & 3.139 \\
\hline & DU-145 & 18.08 & 17.57 \\
\hline & Colo-205 & 6.408 & 6.309 \\
\hline & HCT-116 & 8.443 & 7.812 \\
\hline & A549 & 16.363 & 14.682 \\
\hline & $\mathrm{H} 46 \mathrm{O}$ & 10.73 & 9.291 \\
\hline \multirow[t]{5}{*}{ Mitomyein C } & $\mathrm{PC}-3$ & 1.293 & 1.1155 \\
\hline & DU-145 & 2.072 & 1.355 \\
\hline & Colo-205 & 9.335 & 7.096 \\
\hline & A549 & 15.557 & 12.744 \\
\hline & $\mathrm{H} 460$ & 9.713 & 7.758 \\
\hline \multirow[t]{2}{*}{ Etoposide } & $\mathrm{PC}-3$ & 131.24 & 92.988 \\
\hline & DU-145 & 587.97 & 438.342 \\
\hline \multirow[t]{4}{*}{ Cisplatin } & Colo-205 & 15.525 & 13.623 \\
\hline & HCT-116 & 39.955 & 34.236 \\
\hline & A549 & 48.116 & 32.936 \\
\hline & $\mathrm{H} 460$ & 33.171 & 31.457 \\
\hline \multirow[t]{4}{*}{ 5-fluorouracil } & $\mathrm{PC}-3$ & 10.968 & 8.666 \\
\hline & DU-145 & 18.681 & 13.934 \\
\hline & Colo-205 & 131.511 & 125.417 \\
\hline & НCT-116 & 15.356 & 14.516 \\
\hline
\end{tabular}




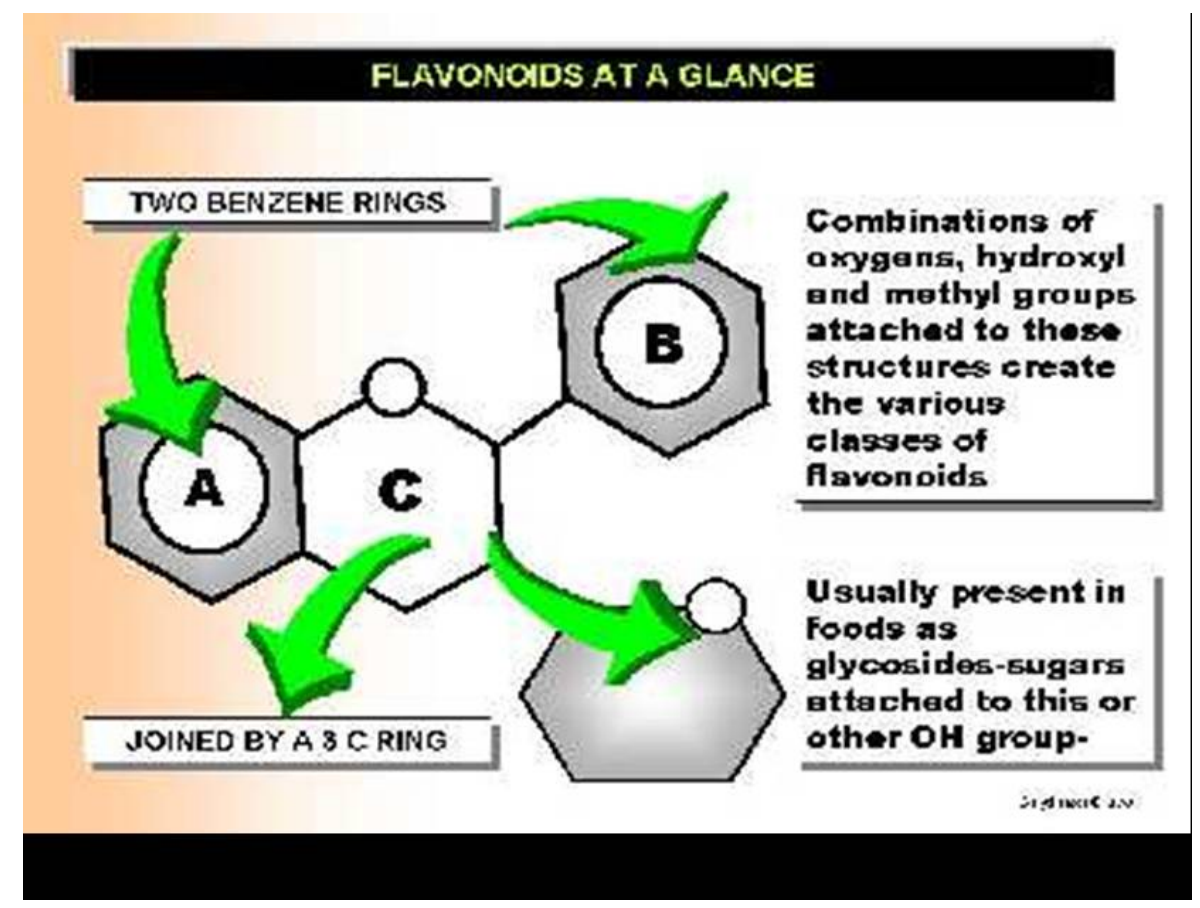

Figure 2.1. The structure of flavonoids.

The general structure of a flavonoid is comprised of two benzene rings joined by an $\mathrm{AC}$ ring. Certain structural characteristics of flavonoids have been shown to have antioxidative and anti-inflammative properties. 


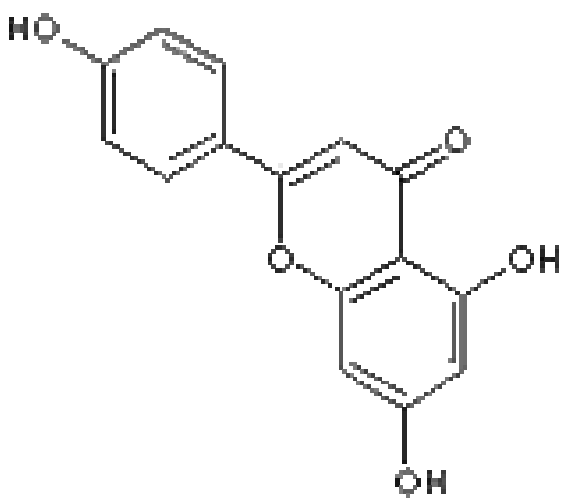

Figure 2.2. The structure of apigenin.

Apigenin, also known as 4', 5, 7 trihydroxyflavone, is a polyphenolic compound that is found in fruits, vegetables, herbs, and a host of other natural sources. It is classified in the flavanol group of flavanoids. 


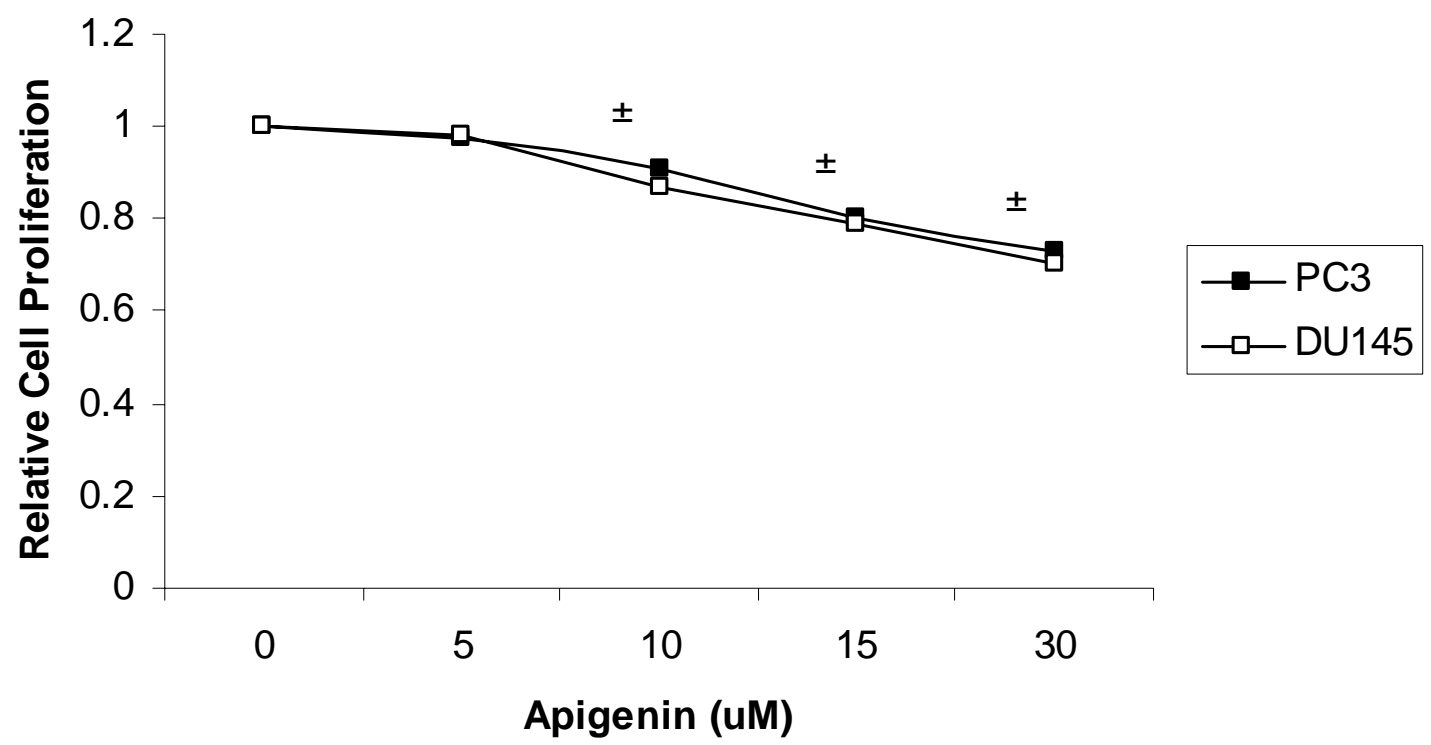

Figure 4.1. Response of prostate cancer cell lines PC-3 and DU-145 to apigenin.

PC-3 and DU-145 cells were plated at 1x104 cells per well in a 96 well plate in $100 \mathrm{uL}$ of media. They were treated with drug in fresh media for 24 hours. $10 \mathrm{uL}$ of MTT reagent (thiozolyl blue tetrazolium) was added to each well before incubating for another 2 hours. Results were read using a spectrophotometer at $470 \mathrm{~nm}$. 


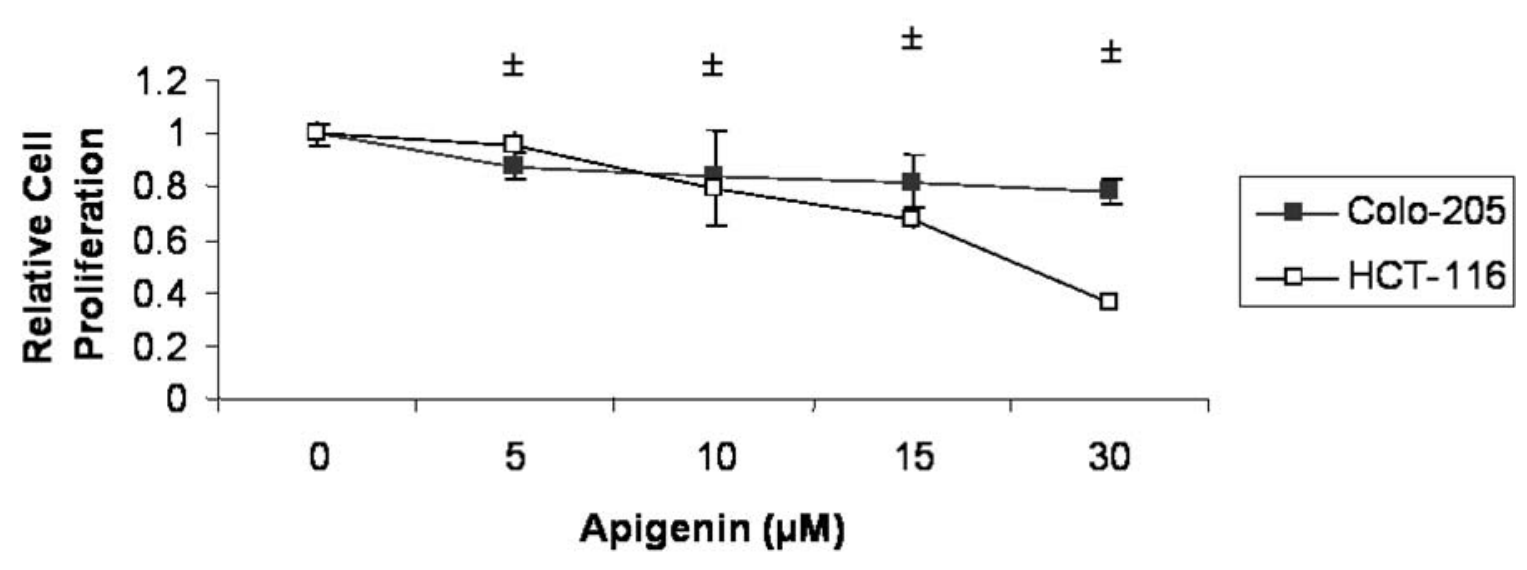

Figure 4.2. Response of colon cancer cell lines colo-205 and HCT-116 to apigenin.

Colo-205 and DU-145 cells were plated at 1x104 cells per well in $100 \mathrm{uL}$ media for a 24 hour drug treatment time. $10 \mathrm{uL}$ of MTT reagent was added to each well before incubating for another two hours. Results were read using a spectrophotometer at 470 nm. HCT-116 seemed most likely to respond to apigenin treatment at higher doses. 


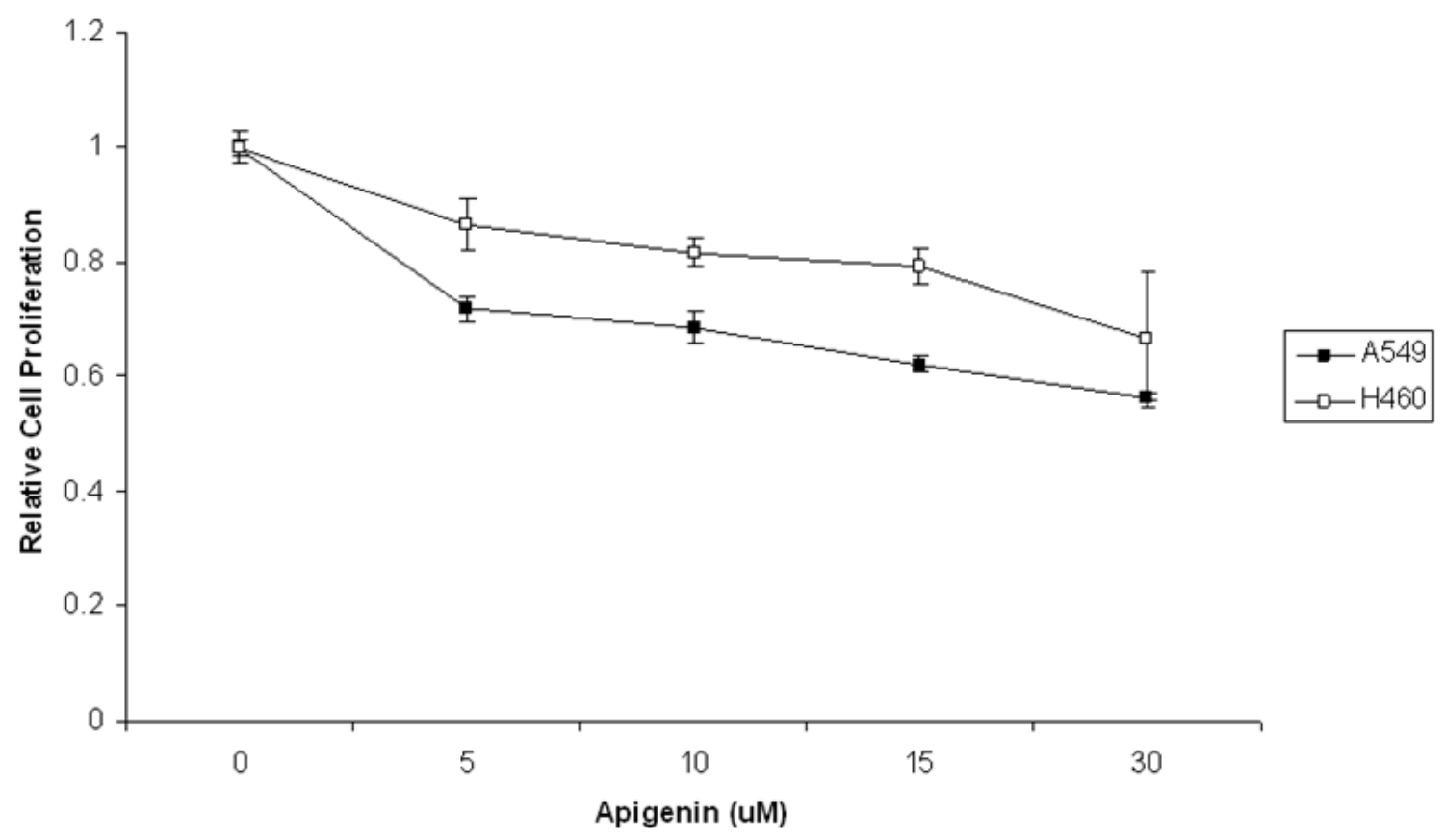

Figure 4.3. Response of lung cancer cell lines A549 and H460 to apigenin.

While both A549 and H460 lung cancer cells decreased cell proliferation significantly, A549 lung cancer cells were most sensitive to the apigenin treatment. 

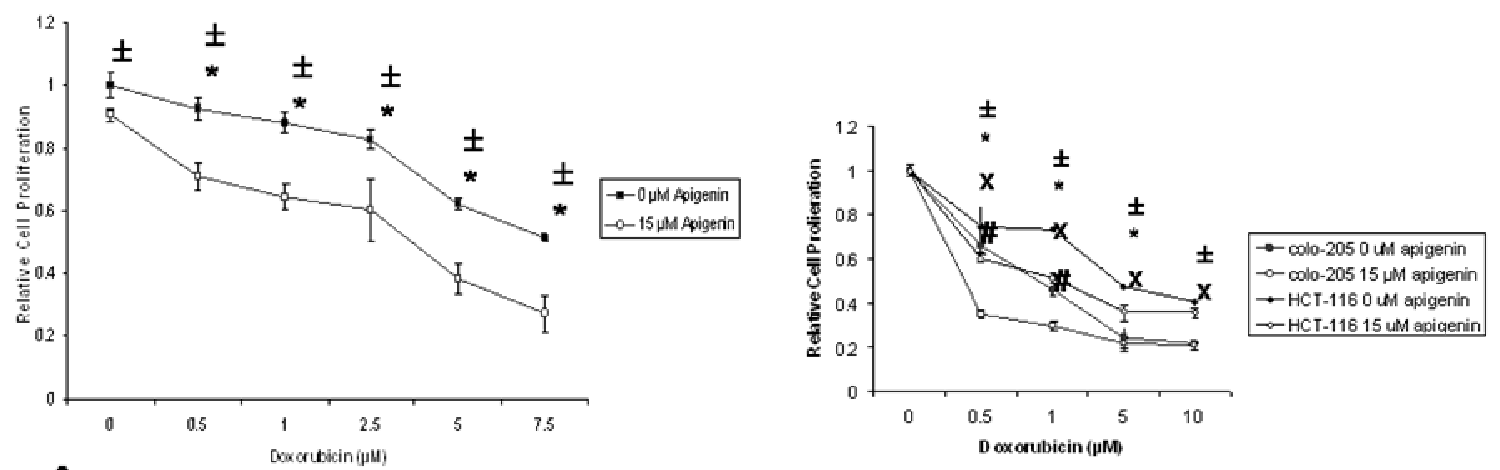

A
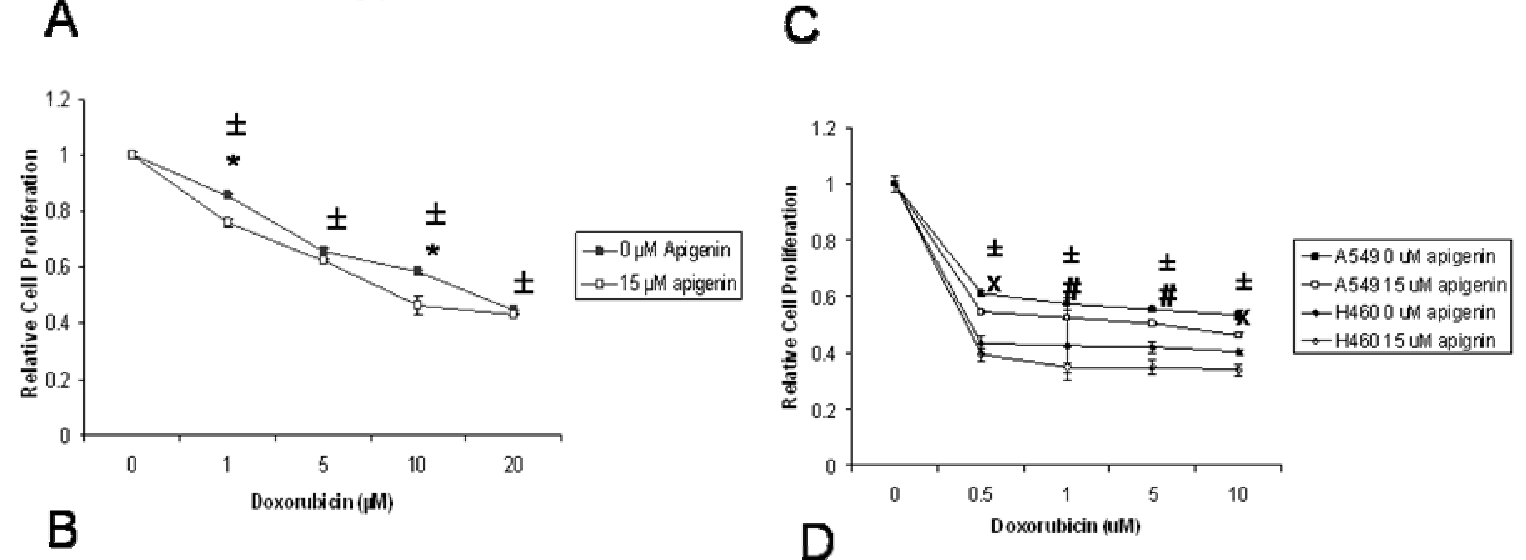

Figure 4.4. Apigenin induced sensitivity of prostate, lung, and colon cancer cell lines to doxorubicin.

Over a range of doses, PC-3 cells (Fig. 4.4a) treated with apigenin seemed to be more sensitive to doxorubicin treatment than DU-145 cells (Fig. 4.4b), colo-205 cells seemed more sensitive at lower doses than HCT-116 cells (Fig. 4.4c), and both A549 and H460 cells seemed to show no trend in significance (Fig. 4.4d). 


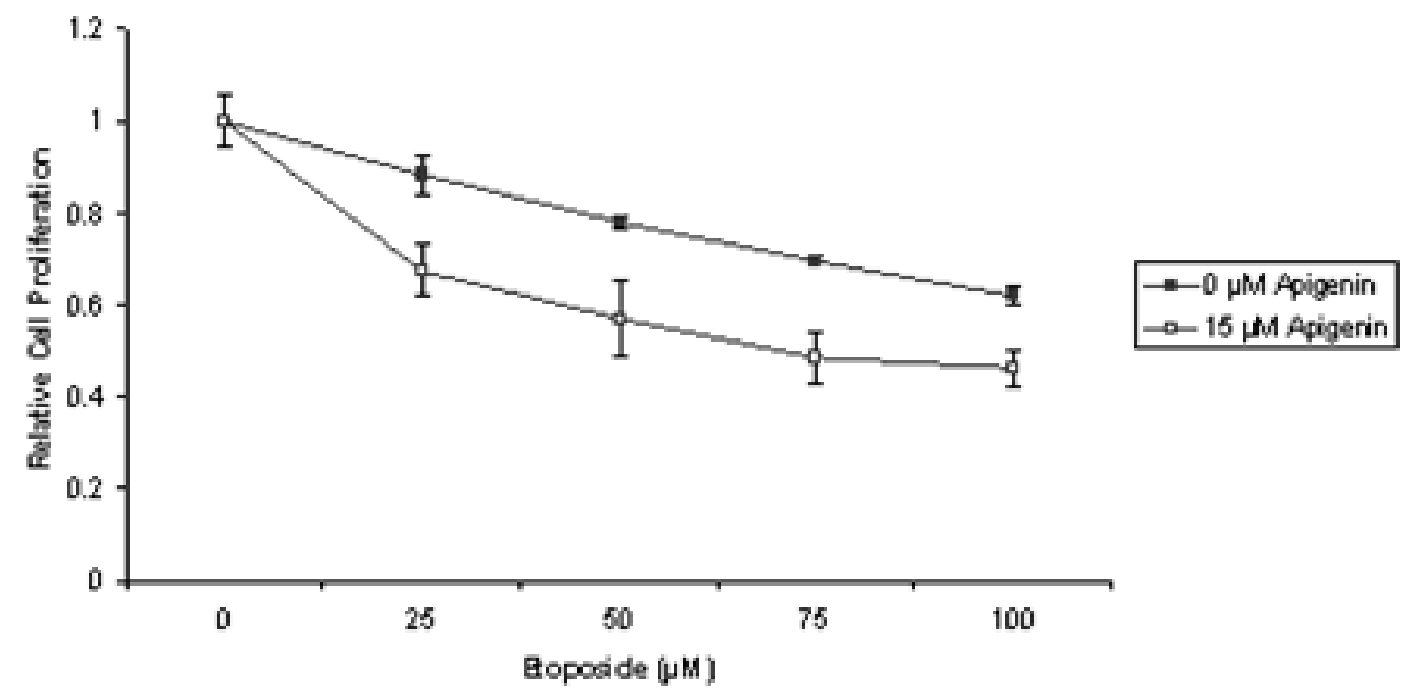

A

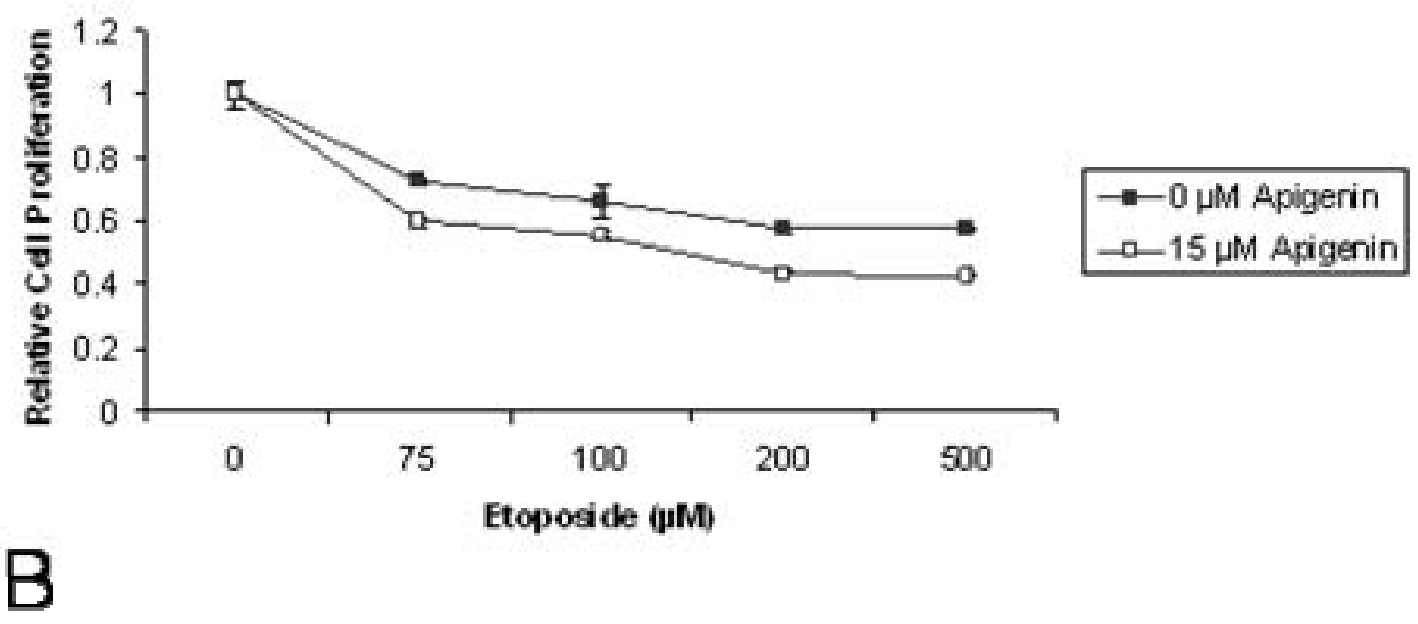

Figure 4.5. Apigenin induced sensitivity of the PC-3 and DU-145 prostate cancer cell lines to etoposide.

PC-3 cells showed a marked sensitivity to etoposide when treated with apigenin in cell proliferation assay (Fig. 4.5a). DU-145 cells showed more drug resistance to etoposide than the PC-3 prostate cancer cell line (Fig. 4.5b). 


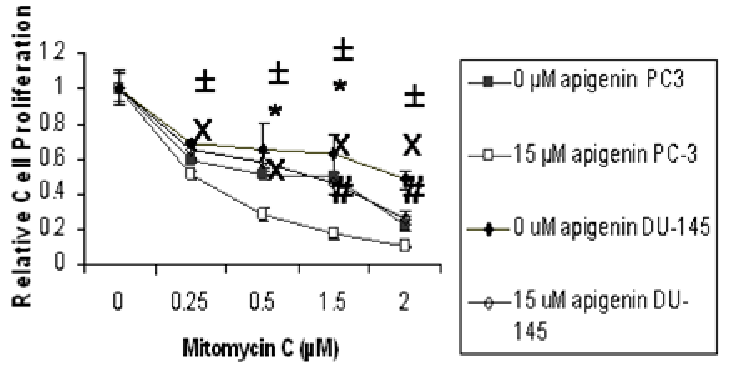

A

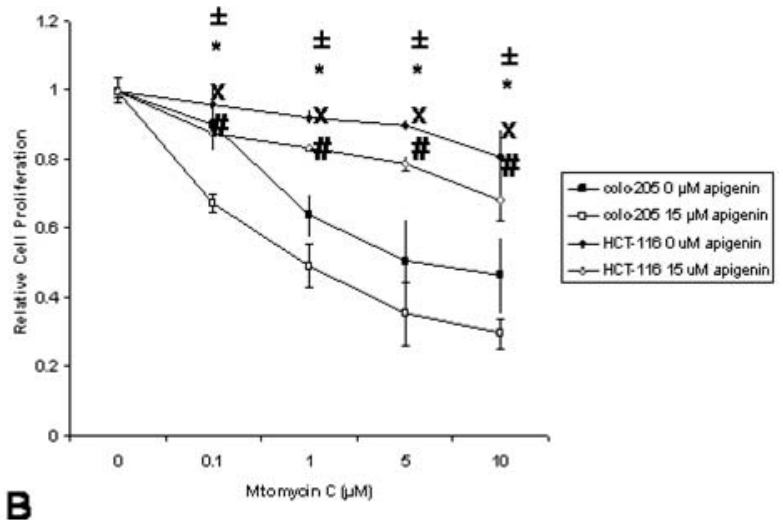

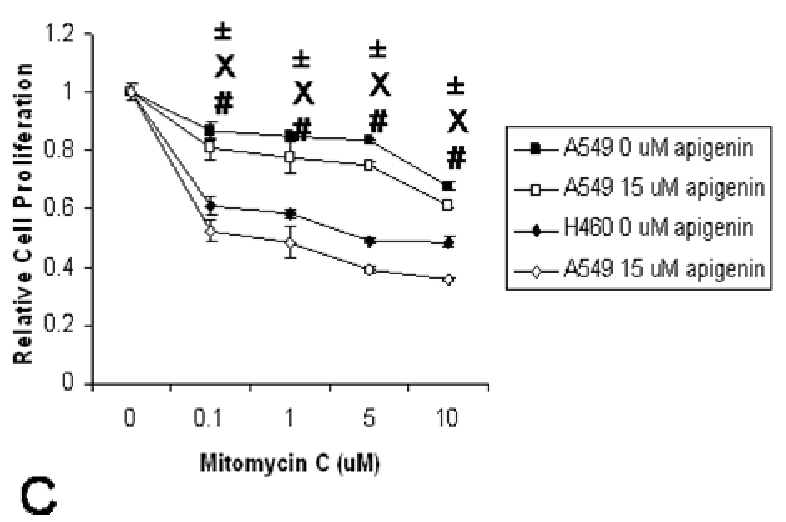

C

Figure 4.6. Apigenin induced sensitivity of the prostate, colon, and lung cancer cell lines to mitomycin $\mathrm{C}$.

Both PC-3 and DU-145 cells showed sensistivity to mitomycin C when treated with apigenin and measured by cell proliferation assay (Fig. 4.6a). Both colo-205 and HCT116 exhibit apigenin-induced sensitivity, however, HCT-116 cells exhibit a much greater sensitivity (Fig. 4.6b). Although both showed a significant decrease in cell proliferation when treating with mitomycin $\mathrm{C}$ and apigenin over mitomycin $\mathrm{C}$ alone, the $\mathrm{H} 460$ cell lines seems nearly twice as sensitive to the effects of mitomycin C (Fig. 4.6c). 

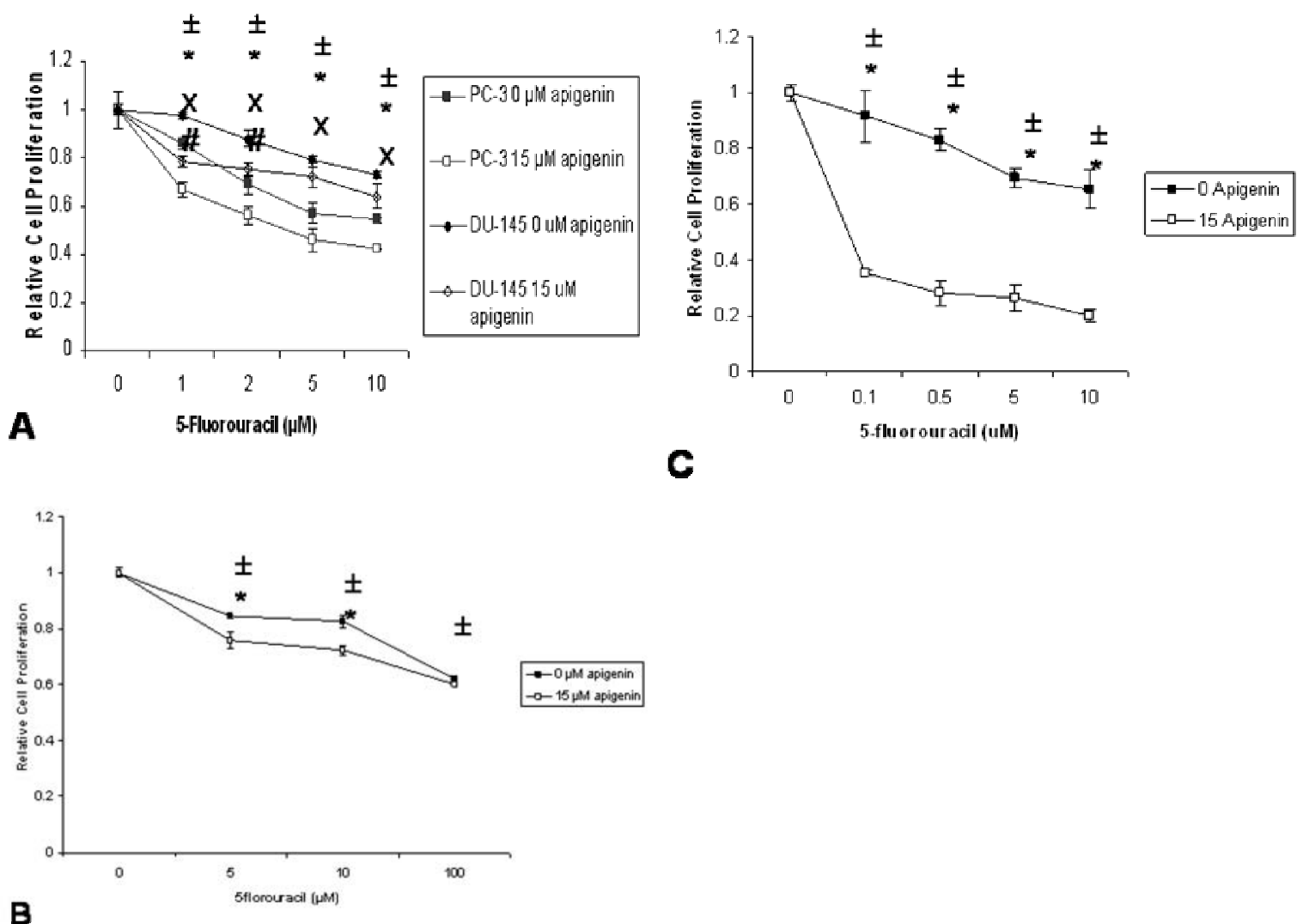

Figure 4.7. Apigenin induced sensitivity of the prostate, colon, and lung cancer cell lines to 5-fluorouracil.

Both PC-3 and DU-145 cell lines exhibited a decrease in cell proliferation, but only the PC-3 cells did so consistently in a dose-dependent fashion (Fig. 4.7a). While both the colo-205 (Fig. 4.7b) and HCT-116 (Fig. 4.7c) cells showed a decrease in cell proliferation with apigenin and 5-fluorouracil, only HCT-116 did so with such a dramatic matter. 


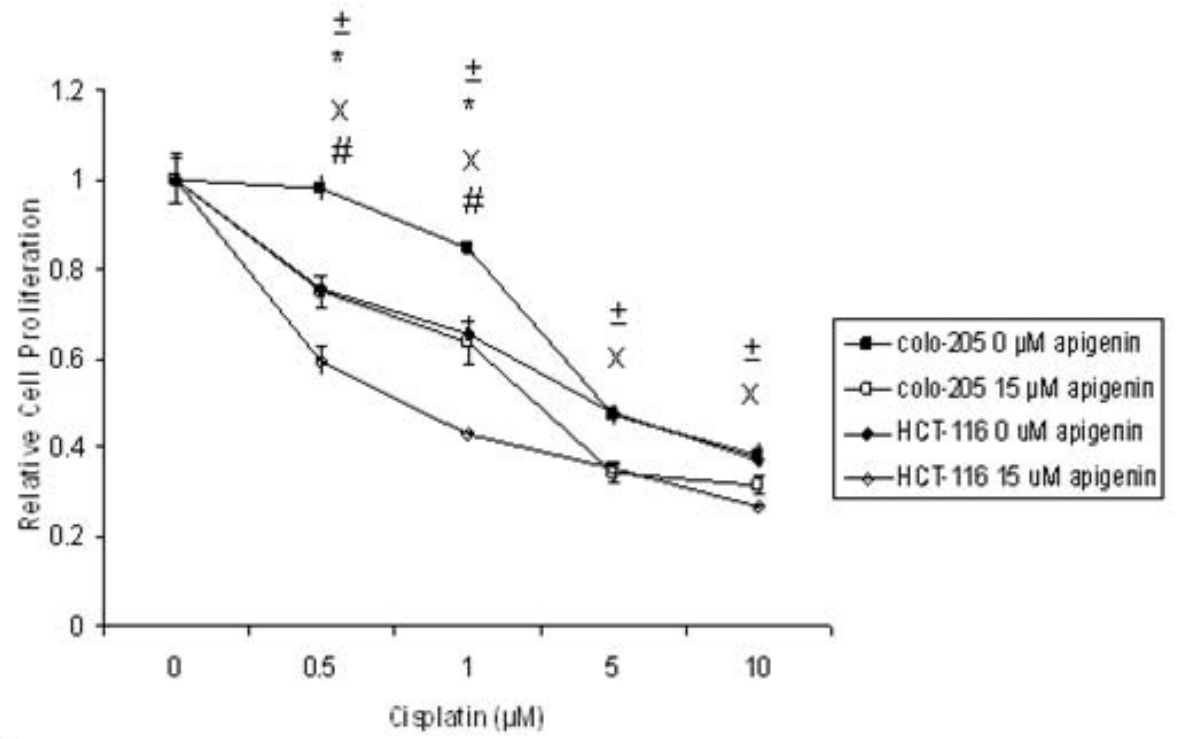

A

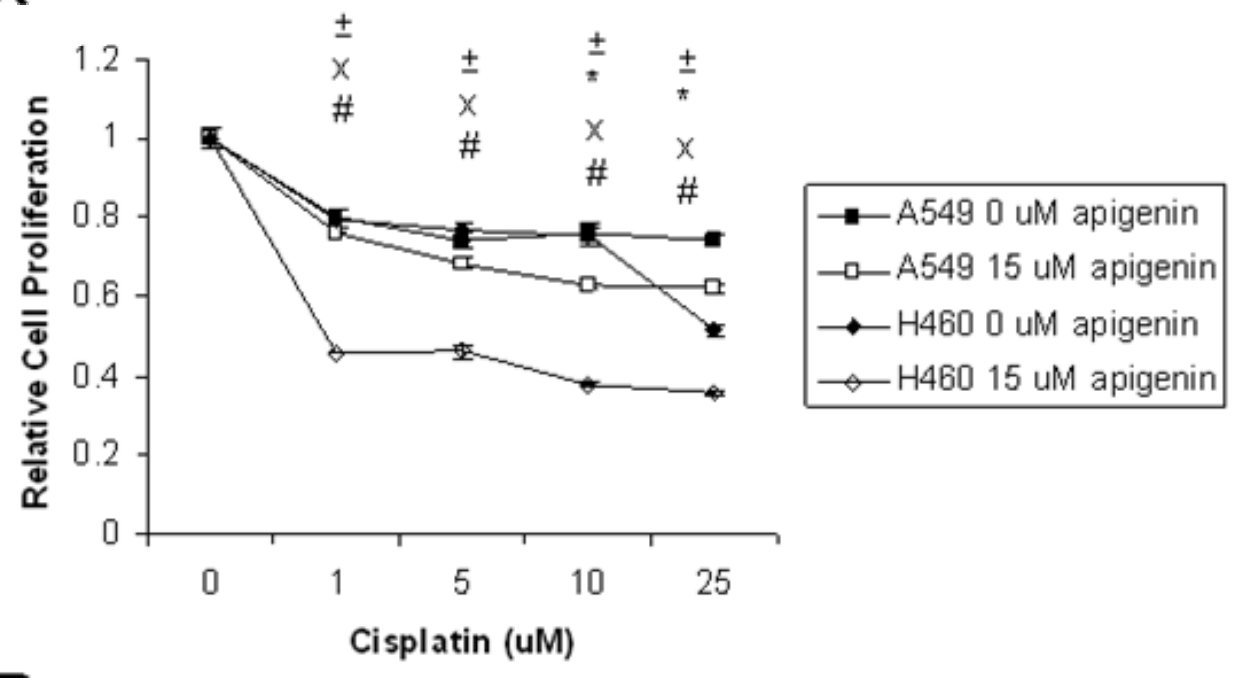

B

Figure 4.8. Apigenin induced sensitivity of colon and lung cancer cell lines to cisplatin.

Apigenin does help increase sensitivity to cisplatin treatment in colon cell proliferation, but only below 5 uM doses (Fig. 4.8a). Like colon cancer cells, lung cancer cells show the biggest increase in sensitivity to cisplatin treatment with apigenin at lower doses of cisplatin (Fig. 4.8b). 


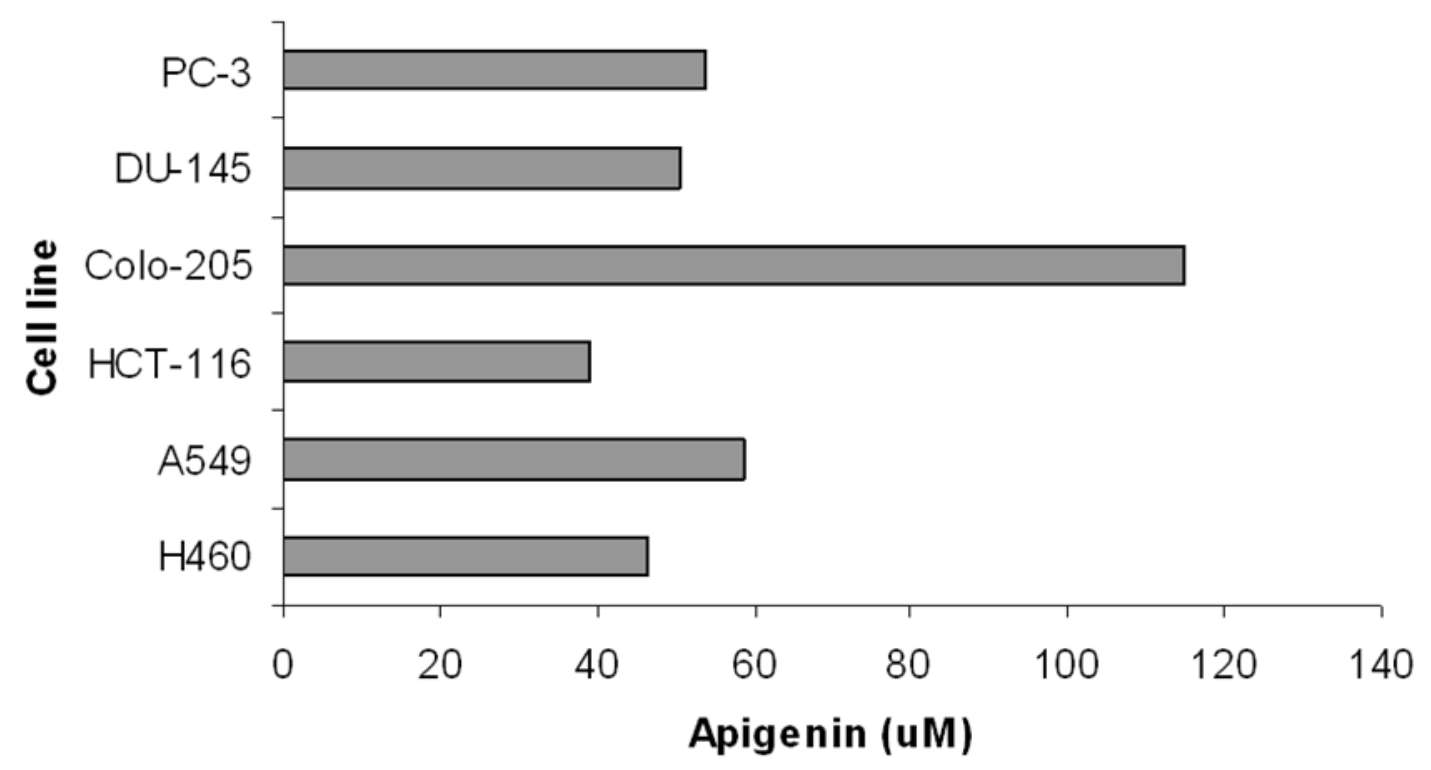

Figure 4.9. IC50's of prostate, colon, and lung cancer cell lines.

The IC50 value, or the dosage at which half the cells in treatment die, vary from cell type to cell type. HCT-116 has the highest tolerance for apigenin, while PC-3 and A549 cells have the lowest tolerable threshold for it. 

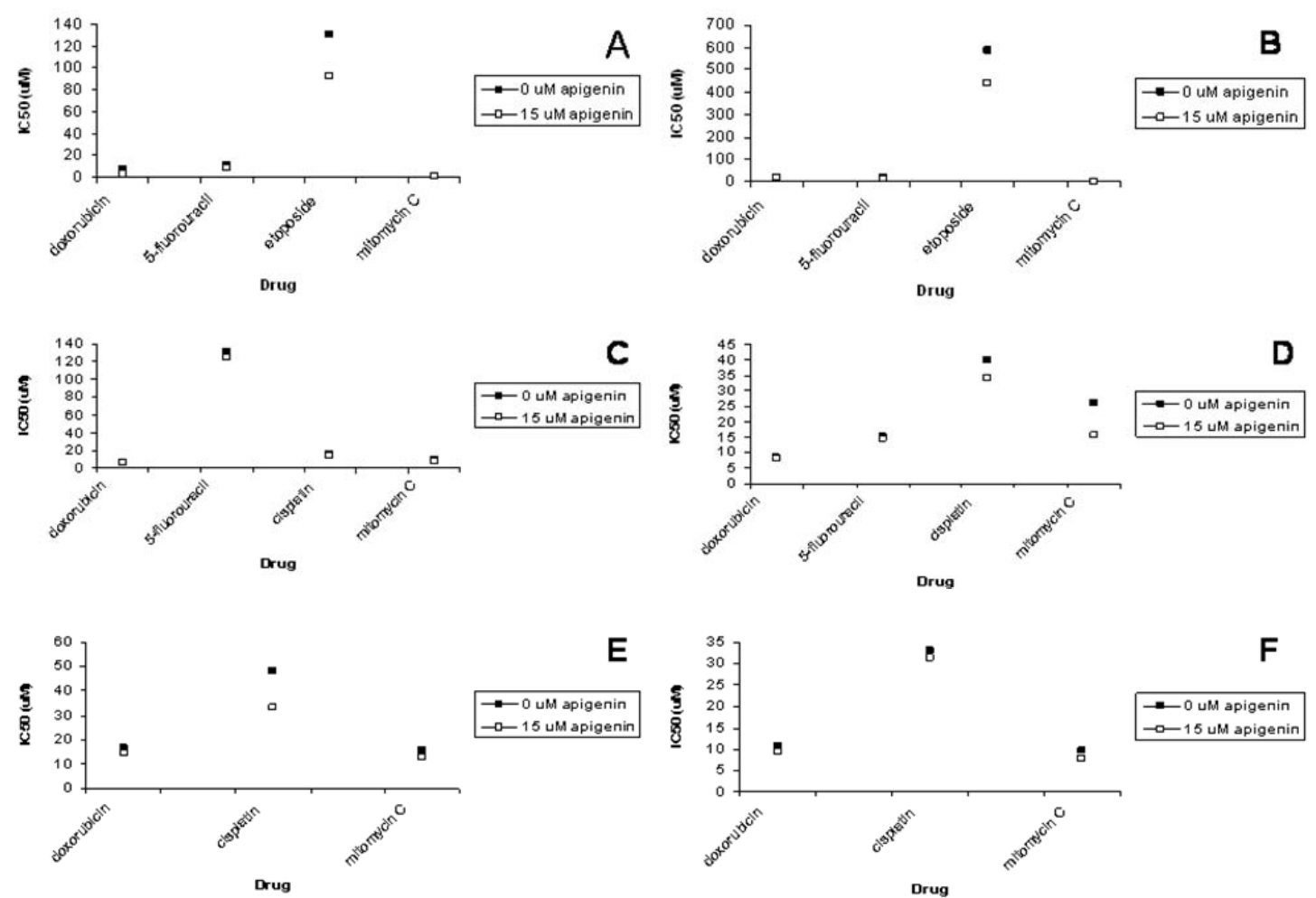

Figure 4.10. Comparison of IC50 response to chemotherapeutics with and without apigenin by drug type.

Apigenin treatment shows the greatest response on IC50 values in PC-3 and DU-145 cells treated with etoposide (Fig. 4.10a and 4.10b), in colo-205 cells treated with 5fluorouracil (Fig. 4.10c), HCT-116 cells treated with mitomycin C (Fig. 4.10d), A549 cells treated with cisplatin (Fig. 4.10e), and H460 cells treated with mitomycin C (Fig. 4.10f). 

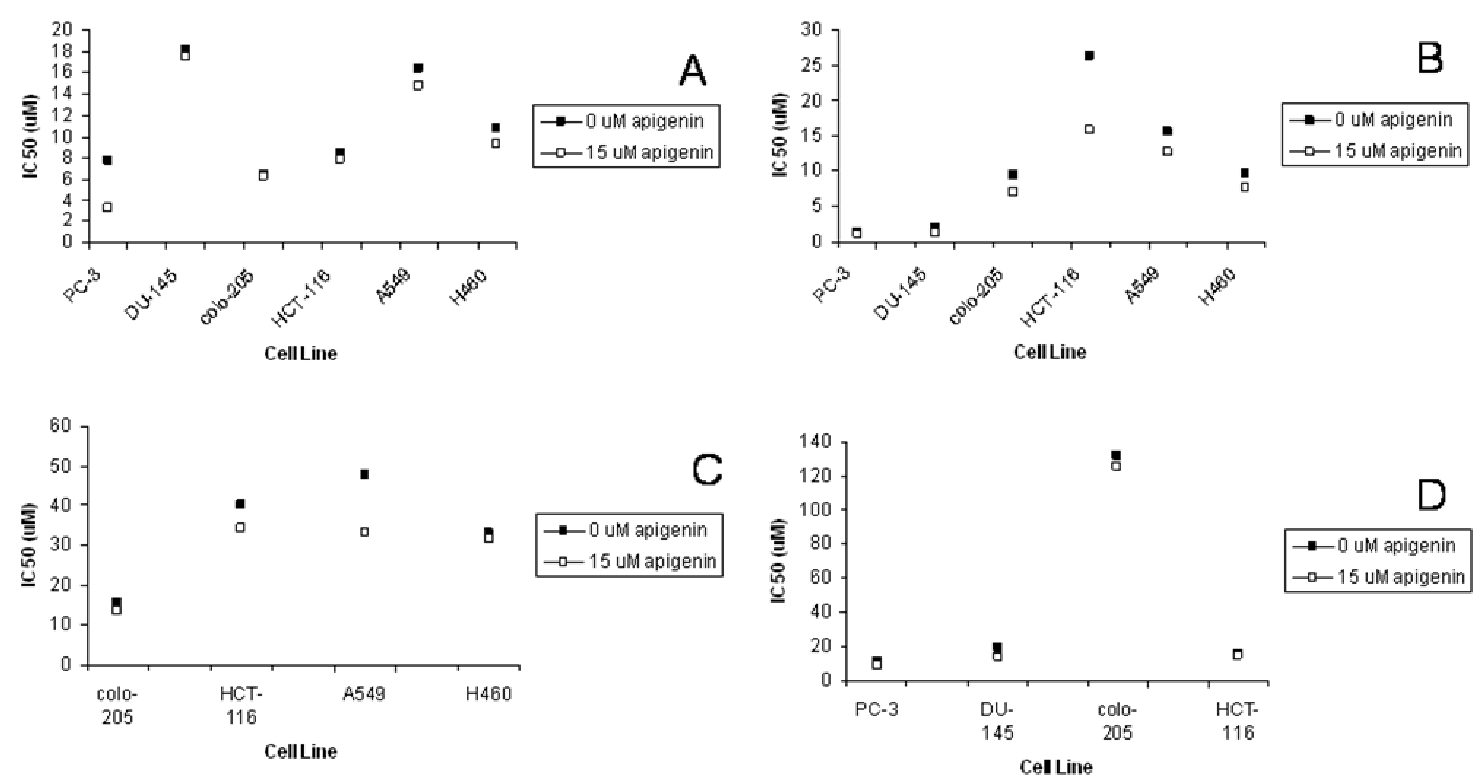

Figure 4.11. Comparison of IC50 response to chemotherapeutics with and without apigenin by cell line.

Response on doxorubicin (Fig. 4.11a), mitomycin (Fig. 4.11b), 5-fluorouracil (Fig. 4.11c), and cisplatin (Fig. 4.11d) varied from cell type to cell type. 


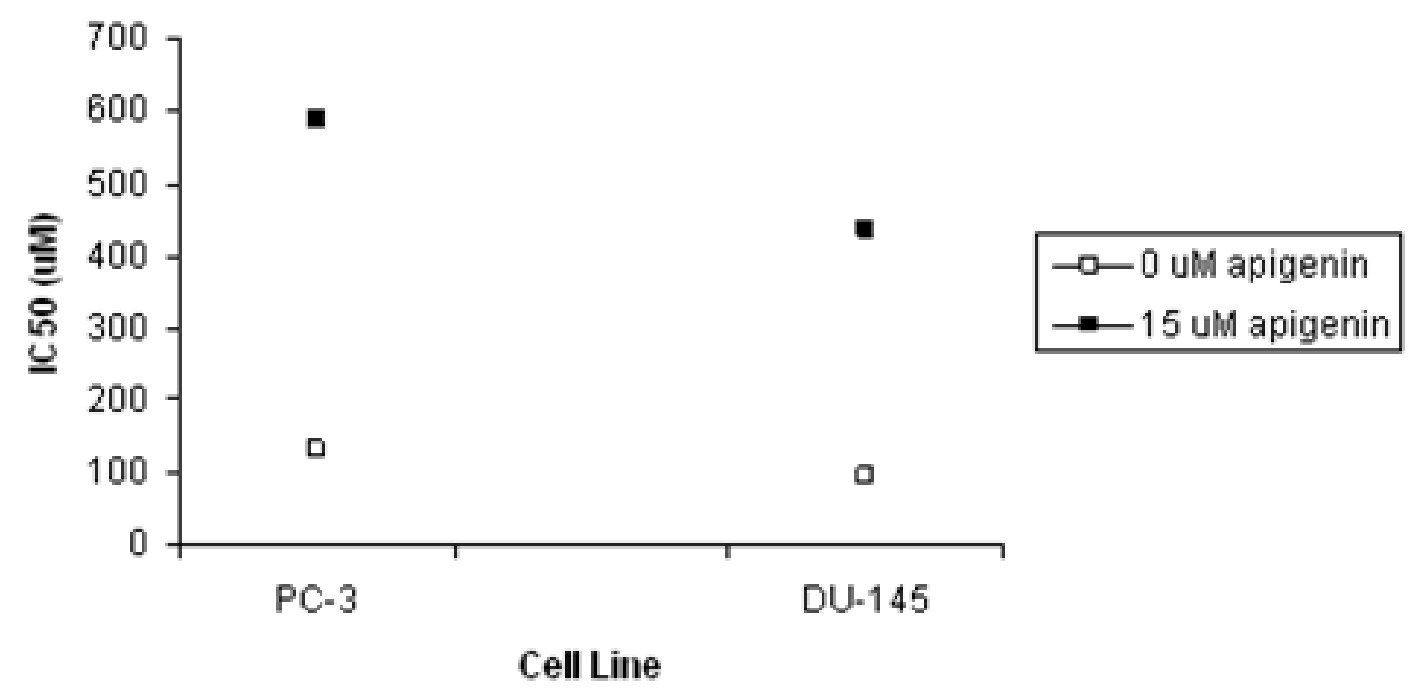

Figure 4.12. Apigenin induced sensitivity of the PC-3 and DU-145 prostate cancer cell lines to etoposide.

Both PC-3 and DU-145 prostate cancer cells showed a significant response when treated with apigenin and etoposide over etoposide alone. 


\author{
Curriculum Vitae
}

of

\title{
Lesly Anne J. Lopez
}

\section{Education:}

\section{Professional Experience:}

Professional Societies :

Publications:
West Virginia University, Morgantown, WV, 26506. Earned Bachelor of Science in Arts and Sciences with a major in Biology. Course work specializing in: scientific and technical writing, ecology and evolution, plant taxonomy, advanced DNA technology. West Virginia University, Morgantown, WV. 2002. May 2002.

Research Assistant. West Virginia University. Robert C. Byrd Health Sciences Center. Mary Babb Randolph Cancer Center. September 2005 to now.

Laboratory Technician. West Virginia University. Robert C. Byrd Health Sciences Center. Department of Surgery. May 2005 to August 2005.

Co-founder and President. Bravo Cell Enterprises. Bridgeport, WV. May 2005 to now.

Graduate Assistant. West Virginia University. Robert C. Byrd Health Sciences Center. Mary Babb Randolph Cancer Center. March 2004 to May 2005.

Laboratory Technician. Marshall University. Joan C. Edwards School of Medicine. Department of Biochemistry. September 2002 to July 2003.

Student Research Assistant. West Virginia University. Robert C. Byrd Health Sciences Center. Mary Babb Randolph Cancer Center. May 2001 - May 2002.

National Association of Science Writers. Student Member.

Mensa Society. Vandalia Chapter. Invited Member.

"Expression of HIF-1 $\alpha$ siRNA affects ovarian tumor growth and angiogenesis." Heath Skinner, Chang Xia, Lesly Anne J. Lopez, BingHua Jiang. WVU Mary Babb Randolph Cancer Center, Morgantown, WV. 95th Annual Meeting of the American Association of Cancer Research. 
"Synergistic effects of lovastatin and a COX-2 inhibitor on apoptosis, cell cycle arrest, prostaglandin synthesis and cell morphology in pancreatic cancer." Linda Vona-Davis, Lesly Lopez, Mary Olive, Alexander Berrebi, and David McFadden. $96^{\text {th }}$ Annual Meeting of the American Association of Cancer Research. 